\title{
Refereeing eParticipation in the Newsroom: The Work Routines and Competences of a News Portal's Discussion Administrators
}

\section{Simon Smith}

Institute for Sociology, Slovak Academy of Sciences, Klemensova 19, 81364 Bratislava, simon.smith@savba.sk

\begin{abstract}
This paper describes the work routines and justificatory vocabulary of online discussion administrators (or admins) based on a case study of a newspaper renowned for its positive outlook on eParticipation. Drawing on interviews and ethnographic observation in the newsroom, it shows how admins deploy a wide range of skills associated with a role that can best be likened to that of a judge or referee, far from the image of the community builder associated with the positive myth about journalism and eParticipation. Although anchored in a sense of the journalistic craft, they distance admin work cognitively from an editorial process and pose problems for workers' professional identity. The paper offers important insights about how an organisation and a profession coped with the need to integrate new tasks resulting from technological change and how the informational value of user-generated content and the participatory competences of online discussants are being actively negotiated.
\end{abstract}

Keywords: discussion administration, discussion moderation, online journalism, work routines, eParticipation

Acknowledgement: The research reported in this paper was supported by a Marie Curie IntraEuropean Research Fellowship, grant no. PIEF-GA-2011-301060.

\section{Introduction}

This paper describes the work routines, the ostensive and the performed scripts of online discussion administrators (or admins) based on a case study of a Slovak newspaper renowned for its positive outlook on eParticipation. Studying the incorporation (or not) of admin work within the professional task repertoire of journalists is of interest because commenting spaces on news portals are "places of boundary work for the journalist-audience relationship" (Robinson 2010: 126). They represent a boundary space in two senses: between journalism and affiliated professions, and between "professionals" and "amateurs". In the first sense, they become an important site for jurisdictional claims and settlements through the enclosure of new tasks (Abbott 1988) or the importation of extrajournalistic skills, identities and practices to the journalistic field (including the entry of people 
whose journalistic credentials are disputed); in the second sense, they can assume the properties of a metajournalistic or even metalinguistic space where cultural production, its quality and the language used by journalists is subject to evaluation and informal sanction by non-journalists (Jacquet 2014) and where the terms of interaction are constantly renegotiated, contested and newly enacted.

While there is an abundance of research dealing with the deliberative quality of online news comments (one could say they replicate, or audit, the administrators' evaluations), comparatively few studies describe commenting policies (e.g.,, Robinson 2010) and fewer still inquire into how comment administration is organised and performed as a cognitive work routine. The main exceptions are Ihlebaek \& Krumsvik (2015) and Degand (2012), and only Degand used ethnographic methods. This is surprising given the long tradition of studying journalism from a sociology of work perspective and the well-established genre of newsroom ethnography, which Paterson \& Domingo (2008) urged researchers of online news production to engage with. My point of departure is a similar research question to Ihlebaek \& Krumsvik's - "how is editorial control practised in participatory services in online newspapers?" (2015: 471) - but turns it much more closely towards situated practice than their survey was able to do. By studying work practices in close-up through a mixture of observation and interviews with current and past admins, the paper aims to describe the skills enacted by admins and understand how they are scripted, consecrated and credentialised by the institutions that structure the organisationsal and professional field.

\section{Background to the Case Study}

\section{1. eParticipation and the Professional Identity of Journalists in Slovakia}

The setting for the study reported in this paper is the Slovak daily newspaper SME, which is the country's third largest daily as measured by average print sales and the leading online news portal. Since the collapse of the communist regime in 1989, the journalistic field in Central Europe has undergone significant structural transformations. The initial effect was to bring in a period of postrevolutionary amateurism when "journalistic practices and routines appear to have been guided more by civic than by professional values" (Metyková \& Waschková Císářová 2009: 728), due to a high turnover of personnel and the foundation of many new titles, but also due to the engagement of journalistists in the struggle to establish democratic institutions.

Throughout the 1990s most new entrants to the profession lacked journalistic training, since it was not until the middle of the decade that the first new journalistic programmes were established in higher education institutions. This can be interpreted as an historical moment of refoundation, when a profession is temporarily amateurised by an influx of new entrants who challenge orthodox practices and values (severely compromised in this case by the higher-level political regime change) before the initially heretical values and practices become embedded as a new orthodoxy. In Slovakia this era was prolonged by the confrontational stance of the third Mečiar government (1994-98) towards the media and other civil society institutions and the reaction of parts of the media, including the newspaper SME, which assumed a strong anti-government stance and practised a 
form of advocacy journalism, identifying with a broad-based "pro-democracy" alliance. Nevertheless, the Mečiar period essentially only delayed a transformation of the journalistic field in the direction of increasing economic heteronomy, influenced by a period of foreign ownership ${ }^{1}$ (between 2000 and 2014 a German publisher held a 50\% stake in SME), increasing sensitivity to commercial pressures and a convergence of journalistic values towards the Anglo-American model of professionalism with its emphasis on accuracy, objectivity and balance (Metyková \& Waschková Císářová 2009). At the same time, however, there seems to be evidence that the journalistic profession is becoming less stable, and some older journalists perceive a crisis in professional values and a decline in self-respect among members of the profession, citing, for example, a tendency for young people to join media organisations merely to make themselves visible so that they can move on to better-paid jobs, for example as spokespeople for economic or political organisations (Waschková Císářová 2007). Survey data indicate that in 2010 around a third of Slovak journalists had considered leaving the profession, mainly for financial reasons, with only $23 \%$ of respondents convinced that they would continue to work in their current organisation (Brečka \& Keklak 2010: 177-179). Professional values thus remain unstable due to the high turnover of personnel and the lack of prestige attached to most positions within the journalistic field, and this instability is only reinforced by the changes to workflows and job descriptions connected to newsroom digitalisation.

\section{2. eParticipation in the Business Model and on the Website of SME}

Like most newspapers, SME took some time to determine the role of a website and online participation in its overall business model, but a number of features stand out in its use of the Internet. It was an early adopter, establishing a website in 1994 (initially in collaboration with a team from the Slovak Academy of Sciences), setting up an online newsroom in 1998 (using the know-how of Valér Kot, returning after postgraduate studies at the Université du Québec), enabling readers to comment on articles before any other Slovak newspaper, and becoming probably the first national newspaper in the world to launch a blog platform for readers' blogs in December 2004 (just before Le Monde offered blogs to its subscribers). Its online news portal quickly established itself as the leading news portal in Slovakia, and was profit-making from 2005. SME has therefore used eParticipation as a key part of its business model, using cultural capital that gave it a head start over most of its rivals. In line with the principle that news organisations should develop online discussion spaces as venues for the free expression of public opinion (World Editors Forum, 2013) SME aspires, in the words of its discussion codex, to sustain "a space for cultivated, substantive and nonaggressive communication between people for the purpose of familiarisation and opinion exchange" (SME, 2012).

This is apparent from a comparison of SME's website with competing news portals in Slovakia in terms of their discussion rules. Of the seven leading news portals in Slovakia according to audience data for November 2014, SME's website does not give an especially prominent place to

${ }^{1}$ It is possible that rising foreign ownership has decreased political heteronomy, on the other hand: Waschková Císářová (2007) reports that one editor-in-chief of a leading Slovak daily felt that direct pressure on journalists from proprietors has been stronger when Slovak media are owned by local capital. 
eParticipation in terms of architecture and visibility, and does not offer features that are lacking on other portals, but it has the most extensive set of discussion rules and they are unique in offering a positive definition of what type of environment the newspaper wishes to create for its readers ("a place of intelligent debate") in addition to simply listing the negative forms of expression that are banned. Its rules are the only ones that are written in the first and second person (referring to the newspaper as "we" and the user as "you") where the norm is to adopt an impersonal third person register. This serves to introduce a conversational tone to the interaction between the medium and its online audience. Finally, only two of the seven portals (SME and Topky) explain in their discussion rules how the alerting system works and encourage readers to use it, thereby indicating an intention to share the responsibility for discussion administration with readers.

\subsection{Commenting on News at SME}

Although many European newspapers initially experimented with a series of different eParticipation channels (blogs, forums, polls and chats as well as interactive devices such as electoral candidate-matching tools), the trend has since been towards standardisation of the eParticipation offer around a single format: comments below articles. Ihlebaek \& Krumsvik (2015) interpret this as an assertion of editorial control, as forums, for example, gave readers more power over the agenda. Newspapers would often suggest broad topics for debate, linked to the "current media agenda" but with the implicit goal of producing something akin to a readers' newspaper. Commenting spaces index the agenda for discussion to the news of the day, as determined by journalists.

eParticipation at SME has followed the same trend (although it also retains a very important place for readers' blogs). It nonetheless differs from most of its local competitors and international counterparts in the way it implements commenting through a range of different administration settings and associated practices. A given article can have one of four types of commenting facility: pre-moderated, post-moderated, moderation delegated to author (e.g., for its "VIP bloggers") and finally articles that are closed to discussion (for topics - notably stories about the Roma - that are seen as particularly susceptible to racist or xenophobic speech). Most, in fact, are post-moderated, but the fact that the treatment of comments at SME has diversified over time is itself significant, because it goes against a general trend towards standardisation (Ihlebaek \& Krumsvik 2015). In particular, the selective introduction of pre-moderation from January 2014 (mostly for articles on science and technology), in an explicit attempt to improve discussion quality, goes against an historical trend for newspapers to switch in the opposite direction, from pre- to post-moderated discussion (Reich 2011). The mixed approach reflects continuing internal debates, uncertainties and experimentation with respect to how to calibrate this apparently standardised eParticipation tool.

\section{Methods}

The paper draws on data from ethnographic newsroom observation and interviews with five current and five former employees of SME whose jobs involved administering online discussion, as well as on interviews and informal conversations with several other managers and journalists. Data were 
collected between mid-2013 and late 2014 as part of a wider collaborative research project between the author and journalists and managers at the newspaper about eParticipation. Former employees were interviewed in cafés or (in two cases) by Skype. Current employees were all interviewed and observed during normal work shifts. The primary purpose of interviews was to produce biographical narratives in order to understand how admin work fitted into journalistic trajectories and professional identities. This was complemented by obtaining respondents' regular CVs.

An important part of the method was developed iteratively in response to a problem that I encountered during newsroom observation. When observing online discussion administration being performed, there were no clearly marked contextual clues about how to interpret what was going on. Job descriptions, official organisational procedures, training manuals and legal codes would have been the natural yardsticks, but these scarcely exist. Discussion administration is a social practice without any codified scripts at SME. But, in order to do the job efficiently, admins nevertheless did what members of organisational groups do in a variety of routine situations - they typified, referring to categories (Sumpter 2000). This meant that it was possible to use research situations to produce textual artefacts that invoked a normative context equivalent to the "missing" standards. Instead of silently observing, I prompted administrators to justify each decision that they took, including the doubts and self-questioning that preceded judgements (Wellens 2011), recording the qualifying words and phrases that they used. The result of this exercise was a series of texts in the form of lists of adjectival words and phrases (Table 1 gives an overview). Adjectives attribute qualities to entities and thus singularise them by referring to a local "context" within which the attributions apply, or by defining legitimate and illegitimate comparisons with other contexts (Chateauraynaud 2003: 231). They referred me to the discursive registers that mattered to individuals at a particular time and place. They invoked a series of standards, norms and categories that oriented their judgement, including organisational policies and values as well as internalised, socialised thresholds of tolerance. This enabled quite a detailed recapitulation of tacit and embodied skills deployed by administrators, referring to (con)texts that do not formally script their work but are made present in its daily performance.

My methodological claim, in line with Weller's approach to studying the invisible deliberative work of magistrates, is that the internal dialogues that accompany individual judgemental work are often better sizable through studying documents - in this case externalised verbalisations recorded by the researcher - than the usual alternative of retrospective interviews (Weller 2011). Thus the texts obtained from newsroom observation - my observation notes of the actions of the administrators and decisions - literally contained their own contexts: the externalised justifications produced in response to my questioning. The textualising research intervention was actually not a violent interruption of normal routine because it corresponded to the textual character of the work itself - the implicit (con)textualisations that form the essence of the admin routine. The subsequent analytical task - and the principal object of this paper - was then to ascertain what registers these justifications referred to, since this is crucial to understanding what kind of legitimacy administrators claim when judging online discussion. 


\section{Results}

At SME, members of staff who administer online discussion are not employed solely in that capacity. When asked, they typically estimated that they spend around $10 \%$ of their working day performing that task, and my newsroom observations suggest that the proportion may even be lower. Apart from the "project manager for user-generated content" (who oversees the process of administration, substitutes for colleagues at busy times and sometimes intervenes in urgent or difficult cases) the task fell on four web editors during the period of this research. The phrase "fall on" is appropriate, because discussion administration is the least important and least glorious element in the bundle of tasks for which web editors at SME are responsible. Admin work is mostly performed at breakneck speed in the brief lulls that occur during a work shift, or failing that immediately after the end of a shift (i.e., in the worker's own time). The day consists of three shifts: $6 \mathrm{am}-12 \mathrm{pm}, 12 \mathrm{pm}-5 \mathrm{pm}$ and $5 \mathrm{pm}$ - midnight. Editors frequently work from home if they have the morning or evening shift, but always come into the office for the busiest afternoon shift ${ }^{2}$.

The four web editors and the UGC project manager are all recent graduates of Slovak universities in journalism or media studies and three of them had worked briefly at other Slovak newspapers or news portals before joining SME. This background contrasts with the profile of their predecessors: Out of around 10 previous administrators whom SME has employed since online discussion to articles was launched in 2004, six had studied humanities or social science subjects and only one studied journalism. Furthermore, their previous and subsequent jobs were more often in the software, new media or creative industries than in journalism. Asked to comment on this change, both the head of online services and one of SME's deputy editor-in-chiefs (previously the founder of SME's blog service and its very first discussion administrator) denied any deliberate change in personnel policy or reassessment of who is best qualified for admin work, but suggested that it probably reflects a gradual stabilisation of the bundle of tasks performed by web editors. Managers have come to the view that discussion administration belongs in this bundle for the simple reason that the person who keeps a close eye on both breaking news stories (in the course of monitoring, adapting and publishing news agency press releases) and the latest audience ratings (in the course of curating the home page) is probably also best placed to supervise what the participatory part of the audience is commenting on. Hence while some of the earlier admins performed discussion administration within a more technical bundle of tasks (e.g., manually uploading content to the web - a task now semi-automised by the content management system), it gradually came to be absorbed within a journalistic portfolio, albeit predominantly composed of the least prestigious areas of journalistic work.

Although in theory (and importantly, in terms of legal responsibility) they should monitor entire discussions, in practice admins rarely have time even to scan the discussion below articles (which

2 One reason is that this is when most of the reporters are finishing their articles for the 'paper' edition, some of which are passed to the editor to put online in draft versions. Another reason is sociability - going for lunch with colleagues, for example. 
can quickly expand to hundreds of contributions spread over dozens of pages)3. Their principal working interface at the time of the study was a list, appearing in reverse chronological order, called the admin notice list or list of alerts. Admins react to alerts received from discussion participants, who pressed a button Alert the administrator and then filled in an online form to explain why they think a certain contribution breaks the discussion codex, selecting from one of five categories of infringement (vulgarity, personal attack, xenophobia/racism, advertising/spam and other) and with the option (relatively infrequently used) to add an explanatory note. The on-duty administrator has to decide if the complaint is valid - and the comment should be blocked - or invalid - and the comment left in place 4 . In this sense the task is analogous to that of a judge or referee in a legal or sporting context. An administrator is, in the words of one former admin, a god-like figure with the power to interpret the rules in force and thus determine what does and does not belong in the comment spaces below newspaper articles. As with judges and referees, to what extent this authority is recognised by discussion participants is an empirical matter, but the latter have little power to contest administrators' decisions, except by commenting.

As explained in section 3, administrators typify the contributions they are asked to adjudicate on, as well as their authors (the discussants). Some typifications are scripted, referring notably to the four codified categories of infringement mentioned above, but sometimes also to a script that tells them it is appropriate to apply different degrees of protection to different categories of discussion participant (discussant, blogger, journalist) or addressee (private person, public person, minority social group, majority social group). In the mid-2000s this was described as an unwritten rule by a former admin (2004-2008), but subsequently - in a rare example of codification - it was systematised in a guidance note written by SME's UGC project manager and made available to editors as a shared Google document. A lot of justifications, however, were not scripted, and refer to categories I have called socially available (typifications with a high degree of social legitimacy in a given historical setting) or embodied / experienced (typifications that the administrator mobilises by reference to precedents encountered in their professional experience or by trusting their instincts, which also tends to come with experience). As Sumpter (2000) has shown, reliance upon experience-based instincts in the absence of codified rules and procedures is also typical of the more glorified editorial routine of selecting stories for the front page of newspapers.

Editors observed and interviewed were thoroughly familiar with the codified categories and often employed their key terms either deliberately or unconsciously when judging comments, but on the other hand they found that they did not provide a sufficient yardstick in many cases, which prompted them to reach for non-codified typifications. Some interviewees indeed reasoned that the competences required to administer discussion are of such a tacit and experience-based nature that they can only be acquired through practice and through asking questions to more experienced

3 The average monthly total number of comments was 100,000-120,000 during the study period.

${ }^{4}$ In practice admins pass a reported comment far more often than they delete it. Overall, SME has a lower than usual rate of comment deletion - about 5\% during the study period according to SME's internal data. This compares with rates (based on journalists' estimates) ranging from less than $10 \%$ to $25-30 \%$ at the newspapers in Singer et al's ten-country study (Reich 2011: 106). 
colleagues. This is partly connected with the belief that SME is blessed with, or has succeeded in cultivating, a discussion community with a unique, slightly exclusive spirit and a higher than usual level of debate, and that the first requirement of a new admin is to get to know the community and acquire a "feel" for the way it expresses itself.

Whether codified or not, admins' typifications basically performed the same function, reducing uncertainty by contextualising the contribution at one of three levels of generality: The level of the discussion itself, the level of the organisation with its "interest" in valorising online discussion as both a commercial and a public service, and finally a more universal level, referring to a notion of the public sphere or democratic society, whether in Slovakia or more globally. Surprisingly few contextualisations invoke the organisational level, which could be because respondents felt it was illegitimate explicitly to invoke organisational considerations as reasons for censoring the content of online discussion, but probably also reflects the highly individualised character of the work itself and the lack of formal opportunities to confer and compare or to receive senior managerial feedback on one's work. As a consequence there is a greater need to explore the other contexts available to the administrator - the "atmosphere" of the discussion thread in which a reported message appears or the way a particular issue is treated in national or international public debate and the idea of generalisable discussion rules, norms and standards.

Table 1 presents a list of evaluatory words and phrases employed by observed admins to justify their decisions. It is selective, of course, but a high degree of saturation was quickly attained during each observation session, as the respondent began to repeat justifications that they had used before. The justifications have been arranged according to the contexts and categories that they explicitly or implicitly refer to.

Table 1: The Administrator's Vocabulary of Evaluation

\begin{tabular}{|c|c|c|c|}
\hline $\begin{array}{l}\text { Context }(\rightarrow) \\
\text { Category }(\downarrow)\end{array}$ & Discussion & Organisation & Universal \\
\hline Codified & $\begin{array}{l}\text { Personal wars } \\
\text { Suspicious numbers } \\
\text { Not aggressive } \\
\text { Suspicious rating } \\
\text { Insult } \\
\text { There's no cause to } \\
\text { attack him } \\
\text { A clear attack } \\
\text { Name-calling } \\
\text { They're maligning } \\
\text { each other } \\
\text { Insults other } \\
\text { discussants in the } \\
\text { third person } \\
\text { Needlessly vulgar } \\
\text { Spammer } \\
\text { Vulgarisms }\end{array}$ & $\begin{array}{l}\text { Insulted our } \\
\text { discussants } \\
\text { Abusing the system } \\
\text { to settle accounts }\end{array}$ & $\begin{array}{l}\text { Just an exchange of } \\
\text { political opinions } \\
\text { Hard-hitting - but } \\
\text { it's about politics } \\
\text { Nothing non- } \\
\text { standard } \\
\text { Completely in order } \\
\text { but it's directed at a } \\
\text { political party } \\
\text { Typical banter in } \\
\text { that context } \\
\text { Typical political } \\
\text { discussion } \\
\text { Doesn't break the } \\
\text { rules } \\
\text { Broke the rules }\end{array}$ \\
\hline
\end{tabular}




\begin{tabular}{|c|c|c|c|}
\hline & Nothing but insults & & \\
\hline Socially available & $\begin{array}{l}\text { Outside the theme } \\
\text { of the article } \\
\text { Artificial support in } \\
\text { the discussion } \\
\text { Doesn't even give } \\
\text { an argument } \\
\text { It has no discussion } \\
\text { value } \\
\text { Off-topic } \\
\text { The post has } \\
\text { nothing in common } \\
\text { with discussion } \\
\text { No contribution } \\
\text { It has no } \\
\text { informational value } \\
\text { It's an opinion } \\
\text { Nothing noteworthy } \\
\text { Nothing valuable } \\
\text { A pointless } \\
\text { contribution } \\
\text { Brings no } \\
\text { arguments } \\
\text { It isn't to the point }\end{array}$ & $\begin{array}{l}\text { We've no interest in } \\
\text { that kind of person } \\
\text { Shows us in a bad } \\
\text { light }\end{array}$ & $\begin{array}{l}\text { Decent } \\
\text { Sane } \\
\text { A normal initiative } \\
\text { Cultivated } \\
\text { Normal } \\
\text { Nothing terrible } \\
\text { Cultivating } \\
\text { Absolute stupidities }\end{array}$ \\
\hline $\begin{array}{l}\text { Experienced / } \\
\text { embodied }\end{array}$ & $\begin{array}{l}\text { Over the line } \\
\text { Overstepped the } \\
\text { mark } \\
\text { Reproducing } \\
\text { conspiracy theories } \\
\text { A big chunk is } \\
\text { copied } \\
\text { Chronic } \\
\text { Stepped over the } \\
\text { line }\end{array}$ & $\begin{array}{l}\text { Matches our taste } \\
\text { That annoys me } \\
\text { That should not be } \\
\text { there } \\
\text { I don't like it } \\
\text { Risk of a law-suit }\end{array}$ & $\begin{array}{l}\text { Pollutes the air } \\
\text { Completely } \\
\text { harmless } \\
\text { Let them fight } \\
\text { Just because ... } \\
\text { A classic case - } \\
\text { we're back home } \\
\text { It's not so bad } \\
\text { It wasn't nice } \\
\text { Pathetic } \\
\text { Slurs his reputation }\end{array}$ \\
\hline
\end{tabular}

\section{Interpretation of Results}

\subsection{Journalism and eParticipation}

Since the widespread adoption of digital technologies by the mass media, journalism and journalists have been challenged to make sense of eParticipation at both a normative and practical level. On the normative level one can find a large corpus of metajournalistic writing shaped by either a positive or a negative myth of online journalism (Domingo 2008). These myths either narrate a need for the profession to evolve a capacity for community management, facilitation and conversation in place of traditional skills associated with knowledge production and textual manipulation in particular, 
or constitute these same trends as a threat to the profession and the professionalism of journalists. Neither discourse does much to elucidate the actual skills required or the nature of the work performed in tasks like discussion administration. This is in part because, whether they reserve a key place for journalists as facilitators or foresee the displacement of journalists from their central place in the public sphere, they tend to overstate the capacity of online spaces for self-regulation and underestimate the work required to maintain them as socially- and informationally-valuable spaces. In a debate about commenting on the US news portal Slate, Will Oremus stated that "moderation is essential and also quite difficult, and is rarely done well." (Hess, Larimore, Marcotte \& Oremus 2014). The evidence from my case study likewise emphasises the demanding nature of the work and its underestimation in organisational workflows and reward systems.

\subsection{The Absence of Ostensive Scripts for New Roles}

Surprisingly, even advocates like Jeff Jarvis, who teaches a university course on social journalism, describe the skills needed for these new roles in similar terms to the "relationship skills" that are demanded of candidates for almost any knowledge-related work ${ }^{5}$. This opacity is reflected in the wording of Slovak job advertisements for web editors and related positions ${ }^{6}$. Candidates are sometimes asked in general terms to display "a good orientation in the environment of the Internet and online communities" or are required to master specific social network tools ("specialist knowledge of Facebook, Twitter and Linked In"), but the ads offer only parsimonious descriptions of what the successful applicant is expected to do (e.g., "administer discussion" or "administer readers' forums so that they are a pleasant place"). More often, in fact, discussion administration is not mentioned at all and ads stress core journalistic skills connected to working with text rather than either communicational or technological competences. If job ads can be taken as a surrogate for a profession's ostensive script, then the dominant trend is invisibility of the work itself and genericisation of the skills it requires ${ }^{7}$.

Journalism, as a characteristically vague profession (Ruellan 1992), has often been uncertain about how to react to technological change. If web 2.0 creates demand for new roles and competences, we find contradictory views about whether or not they belong to the journalistic repertoire - whether they are "dignified" enough to lay claim to (as new competences in which people can professionally excel) or must be rejected as a menace amounting to deskilling or deprofessionalisation. Two of the first discussion administrators at SME said they never thought of themselves as journalists. Current

5 See http:/ / buzzmachine.com/2014/04/26/degree-social-journalism/.

${ }^{6}$ As part of this study I systematically collected all job ads for journalists published on the leading Slovak jobs portal, www.profesia.sk, between July 2013 and December 2014. This paragraph rests on my analysis of that corpus. Job ads play an important role in establishing the normative and customary expectations of both candidates and employers in a given professional sphere (Marchal, Mellett \& Rieucau 2007: 1100).

7 Interestingly, Bourdieu et al's classic study of photography in the 1960s also found that professionals stressed generic and embodied skills such as 'taste' and 'class', as well as polyvalency, as the keys to successful practice, suggesting that it is by internalising and socialising competences as embodied or enculturated that a profession under threat from 'amateurs' attempts to establish distinctions (Bourdieu et al 1965: 271). 
and recent web editors, however, generally did and insisted that the task of discussion administration belongs to the journalistic field. When asked to describe what they do, however, an implicit hierarchy of importance was evident from the very order in which they listed different tasks. Invariably writing tasks were mentioned first (even though web editors do very little original writing) followed by the layout of the homepage, selecting and editing news releases, and perhaps infographical work, with discussion administration usually mentioned last of all. This hierarchy was confirmed when they were asked which aspects of their job they were evaluated upon. Discussion administration became an object of evaluation only in very exceptional and specific circumstances, such as when there was a threat of legal action from a public figure attacked in the discussion. If things were running smoothly, managers did not ask web editors about it. The invisibility of admin work is also apparent from editors' and former editors' CVs and other professional selfpresentations (e.g., on Linked In), and on the staff portraits published on the newspaper's website. Rarely do they mention administration either as someone's skill or as part of their job8.

\subsection{Rearranging Task Bundles and Career Patterns}

Whereas Robinson found a gradual shift in online news comment hosting towards the role of community builder (2010: 140), this research arrives at a different assessment. Robinson's remark actually characterises the case study organisation during the early period of online discussion, when SME was most explicitly committed to the "positive myth" about journalism and eParticipation, but when it also had a separate online division and outsourced part of the labour for discussion administration to non-journalists. Since that time, workflows and task bundles have been reconfigured to pull admin work back into the sphere of journalism by allocating the work to web editors as an integral part of their daily routine. These journalists, however, tend to regard the task as demeaning and management pays little or no attention to the competences it demands in terms of both training and evaluation. In this context, the relatively small time demands of the current admin routine may actually help protect web editors' professional identity against the potential loss of self-esteem associated with having to perform one of the least attractive tasks in the newsroom.

The same can be said about its transitional insertion into career patterns. The turnover of admins is high, both in terms of inter-professional mobility (as we have seen) but also intra-professional and intra-organisational mobility. If a web editor survives a year or two of admin work without suffering burnout, they can expect to delegate the work to someone else and concentrate on more prestigious areas of journalistic work. The task is thus incorporated into the professional repertoire by means of what Abbott calls professional degradation: the delegation of less prestigious work to apprentices and trainees "partly as an initiation ritual in which the ontogeny of the individual career recapitulates the hierarchy of the medical ${ }^{9}$ professions" (1988: 126). Degradation is valuable to professions as a way of maintaining influence over related routine work that they lack the capacity

\footnotetext{
${ }^{8}$ In fact the only person to cite admin work in their CV was one of the ex-admins just mentioned who did not think of himself as a journalist (he works as a freelance translator and website developer).

${ }^{9}$ Abbott was writing about the delegation of menial tasks to doctors in training in hospitals.
} 
to fully "enclose". His examples, however, concern residual rather than new work tasks. Delegating admin work serves instead to stake a claim over a new area of routine work related to journalism, by essentially the same mechanism: Manipulating career patterns to increase aggregate workplace output and thus handle a demand shift caused by the need or the desire to serve a more interactive audience. The additional labour costs to newspapers are effectively absorbed by a small delay in the upward career progress of recent recruits.

\subsection{Discussion Administration as a Performed Script}

The observation of administrators at work, and the performed script that I derived from my observations (summarised in Table 1), revealed that admins deploy a wide range of skills. Administrators needed to be fluent in the formal discussion rules, familiarise themselves with the history of the discussion community and its internal divisions, understand the issue being debated and how it was being treated elsewhere in the Slovak websphere, know how to recognise a good and bad argument, be able to assess compatibility with the "taste" of the newspaper, apply an intuitive feel for the bounds of respectable discourse and adjust this feel according to the differential level of protection owing to particular types of actor. They skipped back and forth between qualifications that apply journalistic standards, treating comments de facto as inputs to news production, and qualifications that imply comments are subsidiary to, or appreciations of, the information produced by journalism (and therefore should not, for example, stray off-topic). Here my findings partially concur with those of Goode that "the norms and processes by which professional editors select and edit user-generated content do not necessarily match those which inform their practices in relation to content generated by professional journalists"10 (Goode 2009: 1303). I argue that it is unhelpful, therefore, to reduce discussion administration either to traditional journalistic work or to the proclaimed new profession of online community building. As is in fact symbolised by use of the term administrator rather than moderator, the thing that the operator takes care of is a system rather than a community. This system is centred on the submission and arbitration of complaints or accusations through an alerting mechanism. The admin then intervenes as the official arbiter or judge. The terminological allusions to a legal process are entirely appropriate. They not only capture the essence of the task but emphasise its symbolic and aptitudinal distinction from the profession of journalism. A possible objection to my legal metaphor relates to the pace of work: Latour (2002) saw programmed hesitation as an intrinsic feature of legal work. The speed of decision-making by admins would appear to contrast with the reflexive meanders that characterise the judgement of professional judges. In fact the difference is much less clear-cut than it would appear- Firstly, there are many legal situations especially in the minor courts where decisions are issued instantly at the close of a hearing, without any visible deliberative pause (Weller 2011). Secondly, admins use several tricks to buy time for deliberation in more complex cases, notably the ability to choose the order in which alerts are dealt with. Thus difficult cases can often remain open

${ }^{10}$ I say my findings partially concur with Goode because I would wish to stress both the extent of divergence and and the parallel presence of deliberate efforts to achieve a normative match. 
(literally in an open tab on the screen) until the end of a shift, when the admin can return to them following an internal deliberative process.

The distinction from journalism is illustrated particularly starkly by the way that the very routine that structures performance of the role pulls the admin away from potentially "valuable" content and towards the disruptions or rule infringements that risk compromising both the reputation of the "brand" and the experience of users (citizens) of an eParticipation space. For example, admins have access to a facility to highlight "top" contributions in a discussion thread, but rarely make use of it, since the alerting routine directs their attention towards bad rather than good practice, and hence they are unlikely to spot many contributions that they want to highlight. If the aim was to extract or highlight content with journalistic value, the admin routine would have to be conceived very differently from how things are done at SME. Tellingly, admins engage in little or no discussion with readers, because they feel it compromises their authority as neutral arbiters to get into debates about the legitimacy of their decisions or the fairness of the rules they implement. In part, this reluctance to discuss is a lesson learned from the experience of the one (ex-)admin (interviewed for this study) who took the opposite approach, but found that his attempt engage in discussion (both to explain and justify decisions and sociably) often met with hostility and accusations directed at him. Asked what qualities made for a good administrator, the deputy editor-in-chief cited above said that they should not enjoy reading the discussions, because enjoyment tends to provoke involvement, which he firmly believed was out of keeping with dispassionate judgment and effective arbitration.

\section{Conclusion}

Based on ethnographic observation of online discussion administrators at work in a leading national news portal strongly committed to eParticipation, this paper problematises common assumptions both about the relationship of the new skills required to facilitate eParticipation to the traditional skillset of professional journalists and about the relationship of the participatory competences that administrators pass judgement on to the critical competences they enact as judges. Admin work requires a specific set of competences that differ in important ways from the editorial skills prioritised in journalism, but which are still highly "professional". The distinct skillset of admins, however, has little to do with community and relationship building. The work routines observed mobilised a hybrid, weakly institutionalised professionalism which was still tenuously anchored in a sense of journalistic craft (verification, orientation in information hierarchies, reference to standards) but put it at the service of an arbitrational rather than knowledge producing function within the "system of vigilance" that oversees how a sociotechnical configuration is kept in order (cf Chateauraynaud \& Torny 2013).

By focusing on the alert system that forms the backbone of admin work (not just) in the case study, and which - strangely, given that "crowdsourcing" administration is seen as a magic bullet by both managers (Touboul 2010) and comment-friendly journalists (Hess, Larimore, Marcotte \& Oremus 2014) - no one has previously studied in detail, this study shows how it routinises the management of comments on online news. "Outsourcing" vigilance thus saves time and resources for newspapers, but it alters the competences needed to perform admin work. Although it facilitates integration of admin work with other editorial work tasks in a temporal sense, it creates a new 
barrier between them in a cognitive sense, by depriving admins of opportunities to review the best comments - and thus to treat comments as input to the news production process.

This conflict between the desire to confer on comments an informational value (implicit in most of the codified rules for discussion) and a tendency to view them as subsidiary feedback on information produced exclusively by journalism (evident in the frequent recourse to socially available categories at the level of the discussion that disqualify comments based on the criterion of relevance or topicality) condenses the boundary work going on around online journalism, where the place of amateurs in professional knowledge production is at stake. Admins are called upon to pass judgement on eParticipatory competence, a competence that is yet to be normalised, given the relative novelty of internet discussion. It has been noted (Tavernier 2010) how newspapers' online discussion rules tend to resemble journalists' own professional norms, but it is equally notable that these norms are contested by discussants, exposing admins to aggressive "inverted reality tests" when evaluators are counter-evaluated by those they evaluate (Smith, Ward \& Kabele 2014). This could explain why codified norms do not exhaust the critical repertoires that admins invoke to make judgements, and particularly the frequent recourse to socially available typifications and universal rules that might be expected to incur legitimacy beyond the journalistic field ${ }^{11}$. My analysis of administrators' justificatory vocabulary illustrates how complex is the process of working out what it means to be a competent discussant of online news - and by extension what it means to be a legitimate referee of internet discussion. Research situated in the practices where participatory competences are negotiated and reproduced - comparing, for example, those taking shape in online news portals with those emerging in other online discussion spaces - thus carries both theoretical import and an important reflexive and pragmatic dimension, as what works, why, where and how is as unclear to organisational and professional actors as it is to academic commentators.

\section{References}

Abbott, A. (1988). The System of Professions. An Essay on the Division of Expert Labor. Chicago \& London: University of Chicago Press.

Bourdieu, P., Boltanski, L., Castel, R. \& de Vendeuvre, P. (1965). Un art moyen. Paris: Minuit.

Brečka, S. \& Keklak, R. (2010). Novinárska profesia na Slovensku 2010. In: Brečka, S., Ondrášik, B. \& Keklak, R. Média a novinári na Slovensku 2010. Bratislava: Eurokódex, 121-210.

Chateauraynaud, F. (2003). Prospéro. Une technologie littéraire pour les sciences humaines. Paris: CNRS Éditions.

Chateauraynaud, F. \& Torny, D. (2013). Les sombre précurseurs. Une sociologie pragmatique de l'alerte et du risque. Paris: EHESS.

11 Especially when one bears in mind that in the research situation the justifications were addressed to me, a non-journalist. 
Degand, A. (2012). Le journalisme face au web: La reconfiguration des pratiques et des répresentations professionelles dans les rédactions belges francophones. Louvain-la-Neuve: Presses Universitaires de Louvain.

Domingo, D. (2008). Interactivity in the daily routines of online newsrooms: dealing with an uncomfortable myth. Journal of Computer-Mediated Communication, 13(3), 680-704.

Goode, L. (2009). Social news, citizen journalism and democracy. New Media \& Society, 11(8), 1287-1305.

Hess, A., Larimore, R., Marcotte, A. \& Oremus, W. (2014). Are Comment Sections Worth It? It takes a lot of moderation to keep the troll population at bay. Slate Plus, Retrieved January 4, 2015, from http://www.slate.com/articles/technology/slate_plus/2014/12/are_trolls_ruining_slate_s_comment_ section.html

Ihlebaek, K. \& Krumsvik, A. (2015). Editorial power and public participation in online newspapers. Journalism, 16(4), 470-487.

Jacquet, A. (2014). La langue des journalistes est-elle dictée par le public? Attentes supposées du public en Belgique francophone. Sur le journalisme, 3(1), 182-192.

Latour, B. (2002) La fabrique du droit. Une ethnographie du Conseil d’Etat, Paris: La Découverte.

Marchal, E., Mellett, K. \& Rieucau, G. (2007). Job board toolkits: Internet matchmaking and changes in job advertisements. Human Relations, 60, 1091-1113

Metyková, M. \& Waschková Císařová, L. (2009). Changing journalistic practices in Eastern Europe. The cases of the Czech Republic, Hungary and Slovakia. Journalism, 10(5), 719-36.

Paterson, C. \& Domingo, D. (eds.) (2008). Making Online News: The Ethnography of New Media Production. New York: Peter Lang Publishing.

Reich, Z. (2011). User Comments: The transformation of participatory space. In: Singer, J. et al. Participatory Journalism. Guarding Open Gates at Online Newspapers. Malden, MA \& Oxford: Wiley-Blackwell, 96117.

Robinson, S. (2010). Traditionalists vs. Convergers. Textual Privilege, Boundary Work, and the JournalistAudience Relationship in the Commenting Policies of Online News Sites. Convergence: The International Journal of Research into New Media Technologies, 16(1), 125-143.

Ruellan, D. (1992) Le professionnalisme du flou. Réseaux, 10(51), 25-37.

SME (2012). Kódex diskutujúceho na sme.sk. http://diskusie.sme.sk/diskusie/kodex/

Smith, S., Ward, V. \& Kabele, J. (2014). Critically evaluating collaborative research: Why is it difficult to extend truth tests to reality tests? Social Science Information, 53, 374-402.

Sumpter, R. (2000). Daily newspaper editors' audience construction routines: A case study. Critical Studies in Media Communication, 17(3), 334-346.

Tavernier, A. (2010). Du professionnalisme journalistique à la professionnalisation citoyenne. Recherches en communication, 34, 99-113. 
Touboul, A. (2010). Journalistes et publics, l'annonce d'un mariage de raison. Communication \& Langages, $165,19-30$.

Waschková Císařová, L. (2007). Report on News Cultures in Slovakia, EMEDIATE Project, WP3 National Report, unpublished report.

Wellens, J.-M. (2011). Comment décrire ce qu'on ne voit pas? Le devoir d'hésitation des juges de proximité au travail. Sociologie du Travail, 53, 349-368

World Editors Forum (2013). Online comment moderation: emerging best practices. A guide to promoting robust and civil online conversation. Darmstadt, Germany: World Association of Newspapers and News Publishers.

\section{About the Author}

Simon Smith

Simon Smith works at the Institute for Sociology of the Slovak Academy of Sciences, where he holds a Marie Curie Intra-European Fellowship on media-hosted eParticipation. He is investigating issues connected with online cultural production, journalists' professional identities and specialised knowledge creation. 